Works of the Faculty of Forestry

University of Sarajevo

No. 1, 2015 (21-37)

UDK $630 * 52: 630 * 24(234.422$ Igman)

\title{
DIAMETER STRUCTURE AND HEIGHT OF TREES DYNAMICS OF FIR (Abies alba Mill.) AND SPRUCE (Picea abies Karst.) STANDS IN MANAGEMENT UNIT „IGMAN“(permanent sample plots 43 and 58)
}

\section{Dinamika debljinske strukture i visine stabala sastojina jele (Abies alba Mill.) i smrče (Picea abies Karst.) u GJ „Igman“ (stalne ogledne plohe 43 i 58)}

\author{
Aida Ibrahimspahil ${ }^{1}$, Besim Balil ${ }^{1}$, Ahmet Lojo ${ }^{1}$
}

\begin{abstract}
This paper analyses the dynamics of diameter structure and height curves as the main indicators of a simple stand structure, uneven-aged multi-storied fir and spruce stands in the management unit Ăgmanñ where selective felling is applied based on the principle of positive selection. The data for analysis was collected by periodical measurement during fifty years on two permanent sample plots, forest sections 43 and 58. It has been determined that during the observation period there had been a change in diameter structure in the sense of increase in the proportion of trees in the lower, and decrease in higher diameter classes as well as the increase of tree height in the complete interval of empirical data. It has been concluded that due to selective felling, with higher diameter classes trees included, conditions have been created for the occurrence of new and the development of the existing young crop; diameter structures of a shape characteristic for even-aged stands have gradually assumed the shape characteristic for selective stands. Thus, due to the increase of competition among the trees of lower diameter classes and the felling of lower height and lower quality trees of higher diameter classes, there has been an increase in the height of trees of the same diameter.
\end{abstract}

Key words: fir, spruce, uneven-aged stand, selective structure, diameter structure, height curve

\section{INTRODUCTION - Uvod}

The process of increment and the development of trees and stands is a complex consequence of a number of variables and factors. These factors act in

\footnotetext{
${ }^{1}$ Faculty of Forestry, University of Sarajevo
} 
Diameter structure and height of trees dynamics of Fir (Abies alba mill.) and Spruce (Picea

abies Karst.) stands in management unit ,Igman“(permanent sample plots 43 and 58)

synergy, thus making researching and understanding the concept of growth and development extremely complex, especially in mixed uneven-aged stands.

An important segment in the research process of tree and stands increment and development, is analysis of the stand structure, since there is a strong cyclic connection between the tree and stand increment and the structure of the stands. A change in the stand structure modifies the conditions for tree growth and its immediate 'neighbours'; the size and character of increment of individual trees changes and the stand structure as well.

Among the numerous indicators of the so-called simple stand structure, the frequency of tree distribution in diameter classes or the diameter structure and the height of trees are considered as the most important ones, since they are the basis for other structure indicators.

Diameter structure is a direct result of development tendencies and changes which occur in the stand. Different stand development phases can be defined through diameter structure and its changes over time, the dynamics of approaching the normal (optimal) condition, are important parameters for forecasting assortment structure, and are thus the basis for any simulation model of stand development.

Height of trees is a factor important for the wood volume of individual trees and stands and it is an indicator of the production potential of a habitat, while the distribution of tree heights in space determines the vertical structure of a stand. In uneven-aged, i.e. selective stands, consisting of trees of different age and growth, height is associated with a diameter. Mean heights of diameter classes make a series, the so-called height curve, characteristic of every selective stand and every habitat, based on which there are numerous and important conclusions.

\section{MATERIALS AND RESEARCH METHODS - Materijal i metode istraživanja}

\section{RESEARCH OBJECT - Objekt istraživanja}

The analysis of the dynamics of diameter structure and height of trees was conducted based on the data accumulated by periodic measurement over fifty years on two permanent sample plots (43 and 58) that are found in fir and spruce forests in management unit 'Igman'.

The management unit 'Igman' encompasses the area of Igman mountain which is a geomorphologic unit together with Bjelagnica mountain, both belonging to the high Dinaric mountains. The climate of this complex is diverse, but generally it is considered mountainous (LUL̦IL, 1966). When considering the flora, Igman and Bjelaginica represent a true image of the flora and vegetation of the continental Dinaric mountains. There are numerous plant species and specific vegetation units as well as their vertical zoning (STEFANOVIĹ 1984). 
In the management unit 'Igman', for the purpose of long-term monitoring of the change in sizes of volume increment and other tree and stand taxative elements, there were ten permanent sample plots established in the period between 1954 and 1957. The sample plots are in different altitudes and mainly in different exposures and land inclination in the forests of beech, fir and spruce and forests of fir and spruce, which are the most common and economically the most important in management unit 'Igman'. The selection of these sample plots was not conditioned by pedological, phytocoenological, i.e. typological base since the area had not been subjected to this kind of research at that time. Eventually, Liril, Stefanovil and Drinil determined soil types and the affiliation to certain plant community (DRINIĹ, 1974; PAVLIL, 1987).

The sample plots in forest sections 43 and 58, which are the object of this research, were founded in 1956. The map of the management unit 'Igman' with the borders of the sections and the location of the sample plots, as well as the satellite images of the specific area of the sample plots and their borders is presented in Figure 1. The scale of the satellite images is different; it has been adapted to the available space.

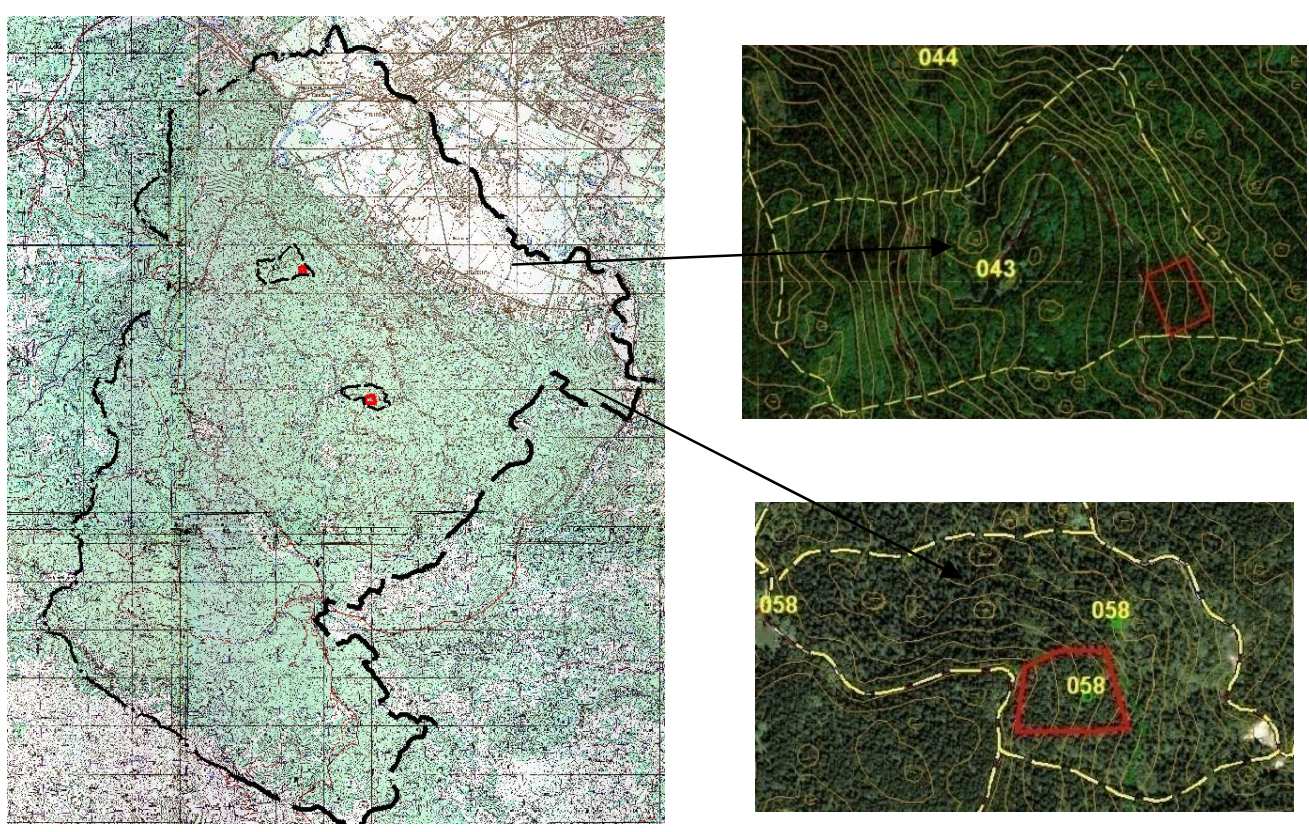

Figure 1. Map of management unit "Igman", borders of the forest sections 43 and 58 with the locations of the sample plots (left), satellite images of the inner areas of sample plots and their borders (right)

Slika 1. Karta GJ „Igman“, granice odjeljenja 43 i 58 sa lokacijama oglednih ploha (lijevo), satelitski snimci užeg područja oglednih ploha i granice ploha (desno) 
Diameter structure and height of trees dynamics of Fir (Abies alba mill.) and Spruce (Picea

abies Karst.) stands in management unit ,Igman “(permanent sample plots 43 and 58)

The basic general and orographic data, vegetation and edaphic characteristics of the researched sample plots are presented in Table 1.

Table 1. Orographic, vegetation and edaphic characteristics of sample plots 43 and 58

Tabela 1. Orografske, vegetacijske i edafske karakteristike oglednih ploha 43 i 58

\begin{tabular}{|c|c|c|c|c|c|}
\hline \multirow{2}{*}{$\begin{array}{l}\text { Sample } \\
\text { plot }\end{array}$} & \multirow{2}{*}{$\begin{array}{l}\text { Altitude } \\
\text { (m) }\end{array}$} & \multirow{2}{*}{ Exposition } & \multirow{2}{*}{$\begin{array}{l}\text { Inclination } \\
\left({ }^{\circ}\right)\end{array}$} & \multirow{2}{*}{$\begin{array}{c}\text { Area } \\
\text { (ha) }\end{array}$} & $\begin{array}{l}\text { Plant Community } \\
\text { (Two Releves) }\end{array}$ \\
\hline & & & & & Soil \\
\hline \multirow[t]{2}{*}{43} & \multirow{2}{*}{1.110} & \multirow{2}{*}{$\mathrm{NE}$} & \multirow{2}{*}{20} & \multirow{2}{*}{1,50} & $\begin{array}{l}\text { 1. Abieti Piceetum illyricum Stef. } \\
\text { 2. Abieti Piceetum illyricum Stef. }\end{array}$ \\
\hline & & & & & Series of soil on limestone. Dominating illimerised soil. \\
\hline \multirow{2}{*}{58} & \multirow{2}{*}{1.280} & \multirow{2}{*}{$\mathrm{NE}$} & \multirow{2}{*}{25} & \multirow{2}{*}{2,63} & $\begin{array}{l}\text { 1. Abieti Piceetum illyricum Stef. } \\
\text { 2. Abieti Fagetum illyricum Treg. }\end{array}$ \\
\hline & & & & & $\begin{array}{c}\text { The predominant brown soil, mainly shallow, sandy soil on } \\
\text { dolomite }\end{array}$ \\
\hline
\end{tabular}

The first phytocoenological releves were made after the foundation of the sample plots and the second ones during the last (fifth) measurement, fifty years later.

During the observation period, there were selective felling on the principle of positive selection made on the sample plots, i.e. trees for felling were selected exclusively from a silviculture point of view.

\section{METHODS OF DATA COLLECTION AND ANALYSIS - Metode prikupljanja $i$ analize podataka}

Diameters at breast height $\left(D B H\right.$ or $\left.d_{1,3}\right)$ and tree heights $(h)$ above the taxative threshold of $10 \mathrm{~cm}$, were first measured immediately after founding of the sample plots. The measurement was then repeated three times every 10 years, while the fifth measurement, due to the past war events, was conducted 20 years after the fourth one. $D B H$ were recorded at every measurement and $h$ during the first, second and fifth one.

$D B H$ were always measured at the same position which had been marked with colour at the first measurement; every following measurement numbered and measured trees that were passed taxative threshold (ingrown trees) and registered a felled trees. Diameter structures were created by distributing trees into diameter classes of $5 \mathrm{~cm}$ and summary statistics were determined. During the calculation of this statistics, $D B H$ were replaced by average diameter classe to which the trees belong, since the original tree diameters of the first four measurements had been lost during the war, while the diameter classes had been saved (PAVLIL, 1987).

Diameter classes of individual measurements were compared to theoretical models often used for presenting diameter frequency distribution. They have been 
compared to Normal, Gamma (3 parameters) and Weibull (3 parameters) distribution. The parameter calculation of these functions and the testing of the significance of differences of empirical and theoretical distribution has been carried out using the software STATGRAPHICS CENTURION, option Distribution Fitting. The KolmogorovSmirnov test (KS) was used for testing the differences.

The changes in the diameter structure in the observation period were analysed by comparing the tree participations in the expanded diameter classes (A: to $30 \mathrm{~cm}$; $\mathrm{B}$ : from 30 to $50 \mathrm{~cm}$; $\mathrm{C}: 50 \mathrm{~cm}$ and higher), while the statistical significance of difference between successive diameter structures was tested using the Kolmogorov-Smirnov test (STATGRAPHICS CENTURION, option Two Sample Comparison).

Height curves for the main species of trees were constructed based on the data of the second and fifth measurement using the method of simple nonlinear regression. Having analysed several different regression models, which are often used to construct sigmoid curves, such as height curves or growth curves of any growth parameter, the Prodans model was chosen:

$$
h-1,3=\frac{D B H^{2}}{\left(a+b \cdot D B H+c \cdot D B H^{2}\right)}
$$

in which: $h \ddot{\mathrm{i}}$ tree height, $D B H$ - diameter at breast height, $a, b$ and $c$-function coefficients.

The size of the coefficients and the regression summary statistics were determined using the software STATISTICA 7.0, option Nonlinear Estimation.

The changes of tree height of a specific $D B H$ in the observation period were analysed by a simple comparison of heights for diameters which represent the limits of expanded diameter classes.

\section{RESULTS - Rezultati istraživanja}

\section{DIAMETER STRUCTURE - Debljinska struktura}

Graphic presentations of diameter structures of the sample plots for the five conducted measurements and the determined theoretical models are presented in Figure 2 (a-d), and the percentage diameter distributions of the number of ingrown (Ni) and felled (Nf) trees in the periods between measurements in Appendix 2. Beside the diameter structures, there are also data on the number of trees per hectare $(N)$ and the size of average diameter by basal area $(D g)$. 
Diameter structure and height of trees dynamics of Fir (Abies alba mill.) and Spruce (Picea abies Karst.) stands in management unit ,Igman“(permanent sample plots 43 and 58)

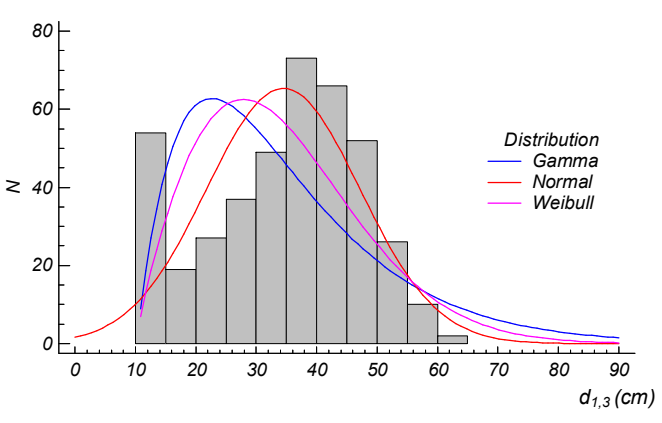

Sample plot 43; N = 267,7; Dg = 36,7

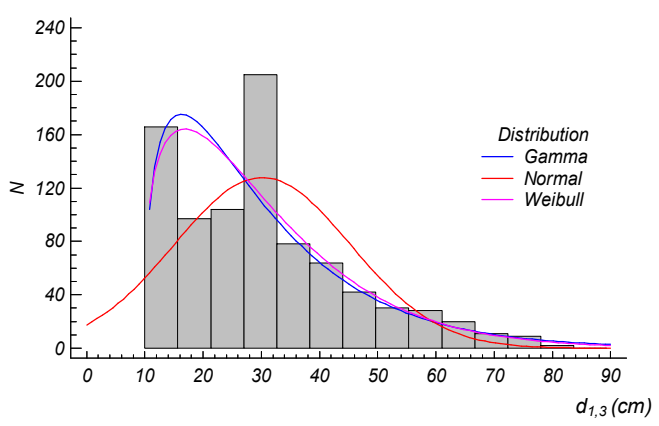

Sample plot 58; $\mathrm{N}=325,5 ; \mathrm{Dg}=33,8$

a) 1. measurement (1956.)

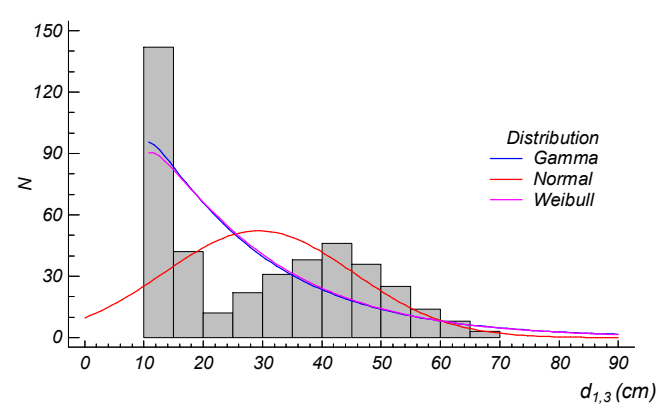

Sample plot 43; $\mathrm{N}=279,3 ; \mathrm{Dg}=33,4$

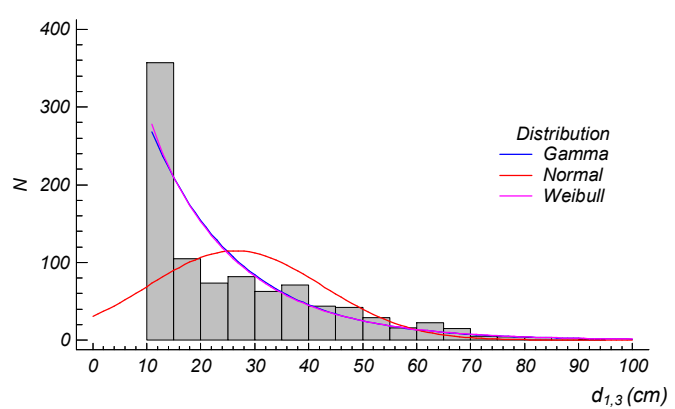

Sample plot 58; $\mathrm{N}=354,4 ; \mathrm{Dg}=31,0$

b) 2. measurement (1966.)

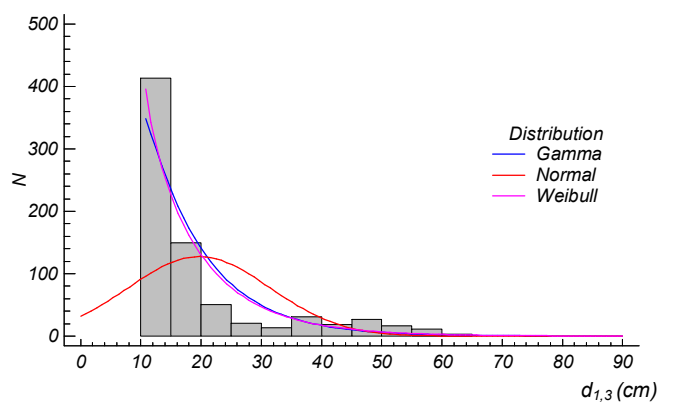

Sample plot 43; N = 502,3; Dg = 22,9

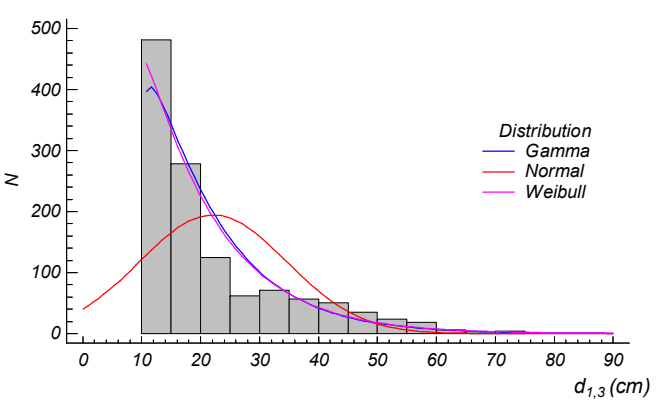

Sample plot 58; $\mathrm{N}=462,4 ; \mathrm{Dg}=25,4$

c) 3. measurement (1976.) 


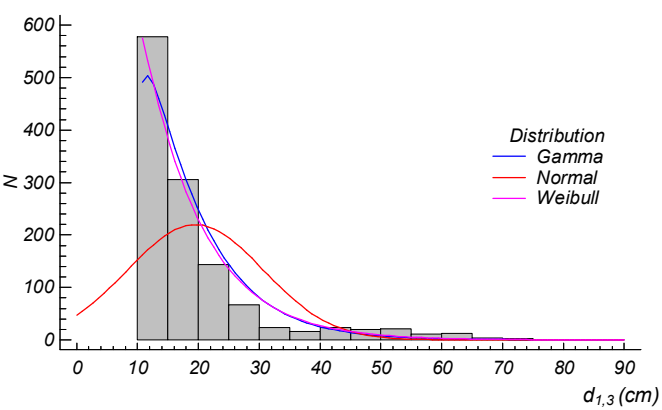

Sample plot 43; $\mathrm{N}=818,7 ; \mathrm{Dg}=22,5$

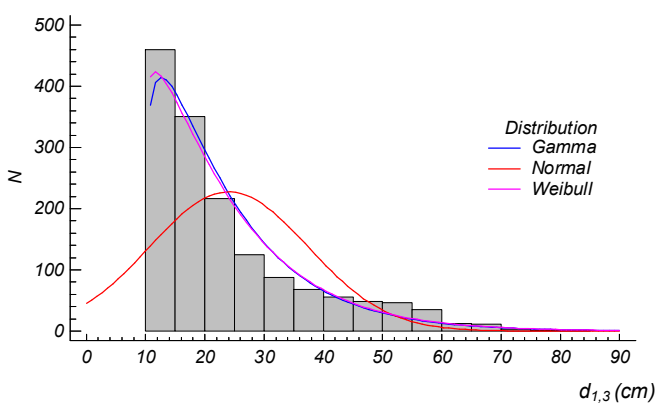

Sample plot 58; $\mathrm{N}=578,3 ; \mathrm{Dg}=27,5$

d) 4. measurement (1986.)

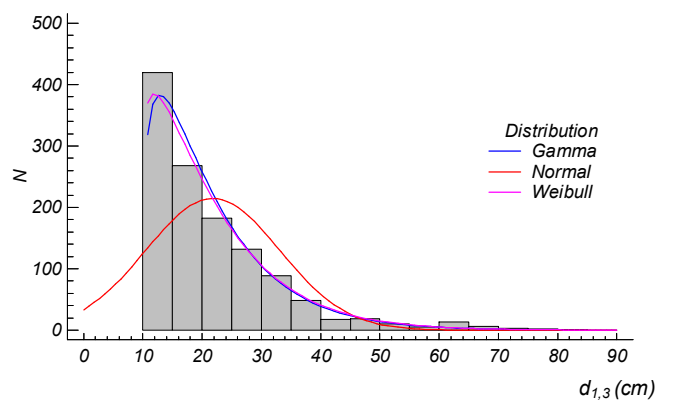

Sample plot 43; N = 810,7; $\mathrm{Dg}=24,4$

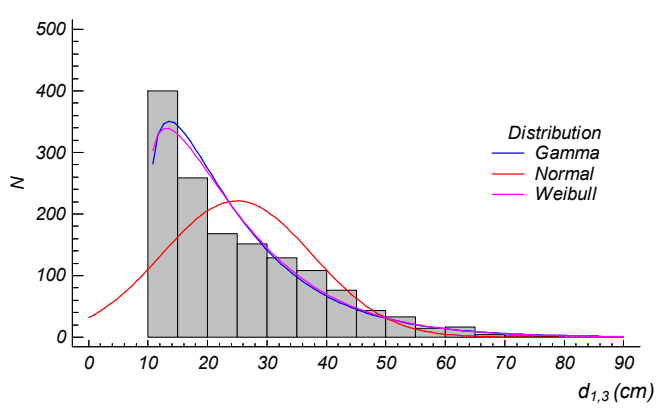

Sample plot 58; $\mathrm{N}=534,2 ; \mathrm{Dg}=27,9$

d) 5. measurement (2006.)

Figure 2. Frequency distributions of DBH for each measurement Grafikon 2. Distribucije frekvencija prsnih prečnika stabala za pojedine premjere

According to the graphic presentations and statistical parameters for frequency distributions (appendix 1) the diameter structures of the first measurement is characterized by a rather small proportion in thin diameter class (A) and a large proportion of the middle class trees (B). During the time diameter structures have changed in the sense of increasing proportion of trees in the lower diameter classes and decreasing in the middle and higher ones, or increase of positive skewness and kurtosis. The exception is the fifth measurement in which determined reduced proportion of trees in the lower and higher diameter classes, and increased in the class of middle diameter, Table 2. 
Diameter structure and height of trees dynamics of Fir (Abies alba mill.) and Spruce (Picea abies Karst.) stands in management unit ,,Igman “(permanent sample plots 43 and 58)

Table 2. Percentage distributions of the number of trees per expanded diameter classes Tabela 2. Procentualne raspodjele broja stabala po proširenim debljinskim klasama

\begin{tabular}{|c|c|c|c|c|c|c||}
\hline \multirow{2}{*}{$\begin{array}{c}\text { Sample } \\
\text { plot }\end{array}$} & \multirow{2}{*}{$\begin{array}{c}\text { Diameter } \\
\text { classes }\end{array}$} & \multicolumn{5}{|c|}{ Measurement } \\
\cline { 3 - 7 } & & 1 & 2 & 3 & 4 & 5 \\
\hline \multirow{3}{*}{43} & $\mathrm{~A}$ & 33,0 & 52,1 & 84,1 & 89,0 & 82,4 \\
\cline { 2 - 7 } & $\mathrm{B}$ & 57,9 & 36,0 & 12,0 & 6,8 & 14,3 \\
\cline { 2 - 7 } & $\mathrm{C}$ & 9,1 & 11,9 & 4,0 & 4,2 & 3,3 \\
\hline \hline \multirow{3}{*}{58} & $\mathrm{~A}$ & 56,7 & 66,2 & 77,8 & 75,7 & 69,7 \\
\cline { 2 - 7 } & $\mathrm{B}$ & 31,6 & 23,6 & 17,6 & 17,1 & 25,3 \\
\cline { 2 - 7 } & $\mathrm{C}$ & 11,7 & 10,2 & 4,6 & 7,2 & 5,0 \\
\hline
\end{tabular}

The largest changes in diameter structures have appeared in the period between the second and the third measurement.

According to the results of the KS test diameter structures of successive measurements, there are significant statistical differences on the confidence level of the $95 \%(\mathrm{p}<0.05)$, Table 3.

Table 3. Comparison of the diameter structures of successive measurements Tabela 3.: Poređenje debljinskih struktura uzastopnih premjera

\begin{tabular}{|c||l|c|c|c|c||}
\hline \multirow{2}{*}{$\begin{array}{c}\text { Sample } \\
\text { plot }\end{array}$} & KS test & \multicolumn{4}{|c|}{ Between Measurements } \\
\cline { 3 - 6 } & & 1 and 2 & 2 and 3 & 3 and 4 & 4 and 5 \\
\hline \hline \multirow{2}{*}{43} & Estimated overall statistic DN & 0,339 & 0,548 & 0,548 & 0,471 \\
\cline { 2 - 6 } & Approximate P-value & $\mathbf{0 , 0 0 0}$ & $\mathbf{0 , 0 0 0}$ & $\mathbf{0 , 0 0 0}$ & $\mathbf{0 , 0 0 0}$ \\
\hline \hline \multirow{2}{*}{58} & Estimated overall statistic DN & 0,383 & 0,396 & 0,396 & 0,302 \\
\cline { 2 - 6 } & Approximate P-value & $\mathbf{0 , 0 0 0}$ & $\mathbf{0 , 0 0 0}$ & $\mathbf{0 , 0 0 0}$ & $\mathbf{0 , 0 0 0}$ \\
\hline
\end{tabular}

The determined diameter structures statistically differ $(\mathrm{p}<0.05)$ from the applied theoretical models of frequency distribution (Normal, Gamma - 3 parameters and Weibull - 3 parameters). Parameter sizes and the KS test results on the confidence level of the $95 \%$ are presented in Appendix 3.

\section{HEIGHT OF TREES - Visine stabala}

Height curves of the second and fifth measurements ( $H C \_2$ and $\left.H C \_5\right)$ separated by tree species are presented in Figure 3, while the size of coefficients and statistic summary of the chosen regression models are presented in appendix 2 . In the graphs are given and the average heights of diameter classes ( $h \_a v g \_2$ and $h \_a v g \_5$ ). 

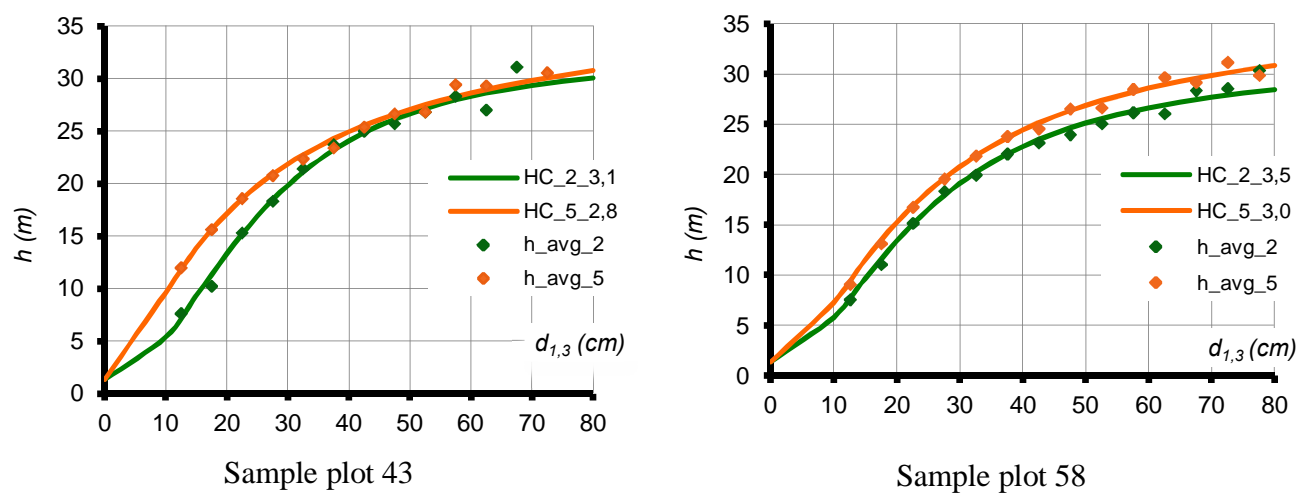

a) Fir
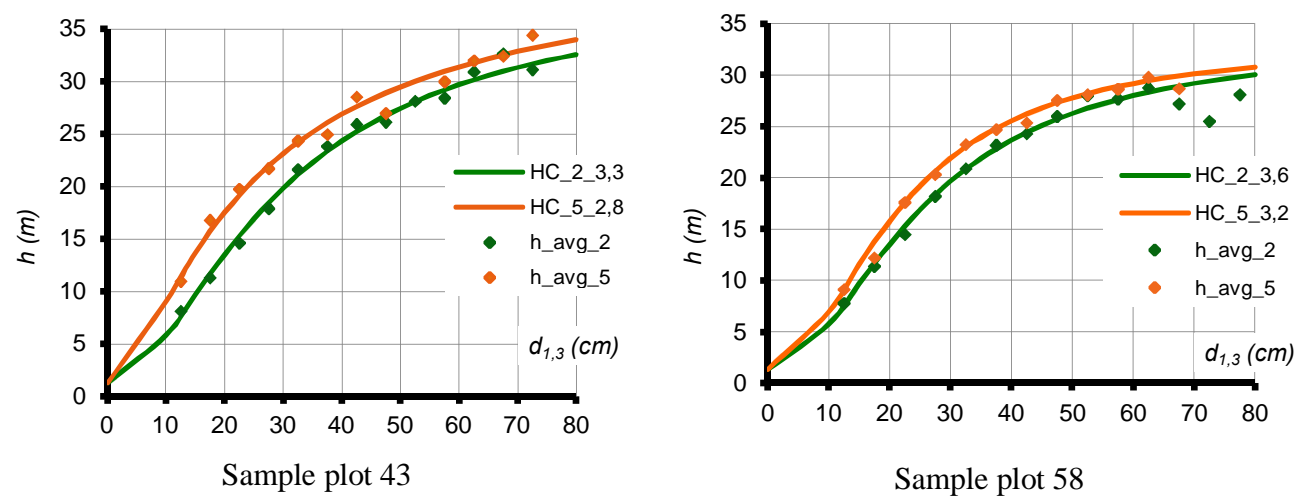

b) Spruce

Figure 3. Height curves and average diameter classes heights Grafikon 3. Visinske krive i prosječne visine debljinskih klasa

Height curves for various measurements are not identical, but in each of the cases they are of a sigmoid shape with significantly longer, less and more expressed, part of degressive increase of trees height with the increase of their diameter.

Trees height in the fifth measurement is, on average, larger that the trees height of the second measurement comparing trees of the same diameter. The differences in height of trees in an absolute and percentage amount in relation to the height at the second measurement for diameters of expanded diameter classes (A, B and C) are presented in Table 4. 
Diameter structure and height of trees dynamics of Fir (Abies alba mill.) and Spruce (Picea abies Karst.) stands in management unit ,Igman“(permanent sample plots 43 and 58)

Table 4. The differences of the estimated tree heights between the fifth and second measurement for limits of the extended diameter classes

Tabela 4. Razlike procijenjenih visina stabala petog i drugog premjera za granice proširenih debljinskih klasa

\begin{tabular}{|c|c|c|c|c|c|c|c|c|c|}
\hline \multirow{2}{*}{$\begin{array}{l}\text { Sample } \\
\text { plot }\end{array}$} & \multirow{2}{*}{$\begin{array}{l}\text { Species } \\
\text { of trees }\end{array}$} & \multicolumn{4}{|c|}{ The differences in absolute amount (m) } & \multicolumn{4}{|c|}{ The differences in percentages $(\%)$} \\
\hline & & 10 & 30 & 50 & 70 & 10 & 30 & 50 & 70 \\
\hline \multirow{2}{*}{43} & JL & 4,24 & 2,00 & 0,39 & 0,47 & 44,18 & 9,16 & 1,44 & 1,59 \\
\hline & SM & 3,27 & 3,29 & 2,03 & 1,53 & 35,85 & 14,21 & 6,87 & 4,65 \\
\hline \multirow{2}{*}{58} & JL & 1,47 & 1,70 & $\begin{array}{l}1,79 \\
\end{array}$ & 2,22 & 20,39 & 8,18 & $6,6,67$ & $7,7,42$ \\
\hline & SM & 1,18 & 2,24 & 1,48 & 0,90 & 17,08 & 10,24 & 5,33 & 3,01 \\
\hline
\end{tabular}

Heights of spruce trees on both sample plots have been changed in the same way. The greatest increase in the absolute amount was determined for trees in medium diameter class, and the smallest for thin trees. In percentage, the largest increase is the height of thin trees, while the height increase of thick trees is the smallest in this case as well. The largest increase in fir trees height in the absolute amount, was determined for thin trees on the sample plot 43, and for thick trees on sample plot 58. The situation is reversed for the smallest increase of fir trees height. Fir trees height increase, if presented in percentage, as for spruce, is the largest for thin and smallest for thick trees.

\section{DISCUSSION AND CONCLUSIONS - Diskusija i zaključci}

\section{DIAMETER STRUCTURE - Debljinska struktura}

Diameter structures of the first measurement are not of a falling curve shape which is a characteristic of selective stands. These structures, due to a large participation of medium thick trees, remind of diameter structures of even-aged stands and thus imply the remaining virgin forest features (MATIL 1980). This was specific of most beech, fir and spruce forests in Bosnia at the time of founding the sample plots, and it is directly connected to the fairly short amount of time since virgin forest began to be transformed into economical forests.

An increase in the participation of thin trees has been ascertained as well as the decrease of the participation of medium thick trees, which is a direct consequence of the felling in the period between individual measurements and tree increments, entry trees in the inventory part of the stand (ingrown trees) and the next higher or even greater diameter degrees.

Stronger intensity felling, which had been undertaken on both sample plots immediately prior to the second and third measurements, including medium thick trees to the greatest extent, influenced a more significant change in diameter structures. Due to more free space and larger quantities of light in the stands, these felling have 
resulted in a greater intensity of ingrown trees and an increase in the participation of thin trees, thus forming diameter structures of a falling curve form. Minor differences in diameter structure forms in the following periods, between the third and fourth, and the fourth and fifth measurements, are connected to lower intensity felling which mostly included thin trees of which an important part is mortality due to competition. This relates to the period between the fourth and fifth measurements which is twice longer than other periods, due to war, and without regular felling.

Based on the shape of diameter structures and their changes, regardless of the aberrations from the óregularômodels, it can be stated that by using selective felling on the principle of positive selection, a selective structure, or one similar to it, has been created.

Based on the values of homogeneity index $(\mathrm{H})$, determined for diameter classes of $5 \mathrm{~cm}$ (IBRAHIMSPAHIL, 2012), a selective structure was achieved at the second, third and fourth measurement on the sample plot 43 (H: 2,58; 2,18 and 2,63), and in the third measurement on sample plot $58(\mathrm{H}: 2,79)$. Aberrations from selective structure are a consequence of a larger participation of medium thick and thick trees. Aberrations of diameter structure from a regular falling curve diameter structure, due to the 'lack' or 'surplus' of trees in individual diameter levels, according to MATIĹ (1980) are a common appearance. Achieving an ideal diameter structure in a specific stand and with rational management is rarely possible, and if it does happen it is difficult to be maintained.

The determined changes of diameter structures are in accordance with the results of selective forest structure research according to which a diameter structure in the form of falling curve is formed if selective felling is carried out over a longer period of time (LIOCOURT, 1899 according SCHÜTZ, 1989; MEYER, 1933 according KOTAR 2005).

It is important to notice the research results of BONL INA and DEVJAK (2002) and KOTAR (2003) according to which the functioning of forests, as selective ones and fulfilling goals over decades, is possible even in case of deflection of the diameter structure from the regular shape. KOTAR (2003) came to the conclusion that the calculated theoretical frequencies according to the Liocourt formula are not the necessary condition for a balanced state, and that there is not a completely balanced state and thus it is more appropriate to use the term 'state of dynamic balance'.

The determined 'loss' of selective structure, after it has been achieved according to the homogeneity index size, is in accord with the already known notion that selective forests are biologically stable and structurally unstable (AMON, 1944; FLURY, 1933 and LeIBUNDGUT, 1945, according MiLetiĹ, 1950; MatiĹ, S., et al., 2001) and that the manner of management demands long-term consistent work and ample knowledge and experience at the selection of trees for felling (BONL INA, 2011). 
Diameter structure and height of trees dynamics of Fir (Abies alba mill.) and Spruce (Picea

abies Karst.) stands in management unit ,Igman "(permanent sample plots 43 and 58)

\section{HEIGHT OF TREES - Visina stabala}

Different shapes of height curves imply the variety of stand structure, site conditions, height and diameter increment flow and the foundation of selective structure.

According to the determined height curve forms, an increased diameter increment and decreased height increment, trees of $25-40 \mathrm{~cm}$ diameters can be characterized, while the diameter increment for trees over $40 \mathrm{~cm}$ is even larger with a lower height increment.

These results are in accordance with MILETIL (1950), since one can notice the appearance of a period of large increment in lower diameter classes based on height curve forms. These results are also in accordance with BURGER (1941 according MILETIL ,1950) who also notices that an abrupt decrease in height increment sets in at diameters $20-40 \mathrm{~cm}$, when trees are in a more open space and cross from the lower into the higher layer.

The changes in tree height, i.e. the difference in height curves, is a consequence of the difference in stand structure due to the application of different intensity felling and the change in wood volume and diameter and height structure of the stands (FLURY, 1933 and LEIBUNDGUT, 1945 according MILETIL, 1950; MitSCHERLICH, 1952 according KOTAR, 2005; KLÄDTKE, YUE, 2003; KOTAR, 2005).

The determined tree height increase in the entire interval of empirical data, during the period the height curve changes were analysed (40 years), is in accordance with diameter structures of the stands. This period saw an increase in the number of trees, mostly thin trees $(10-30 \mathrm{~cm})$; the participation of medium thick trees $(30-50 \mathrm{~cm})$ was decreased, while the participation of thick trees was increased. In some cases, we saw the increase in the diameters of the thickest trees. In such conditions, there is serious competition between trees, especially between thin and medium thick trees; trees maintain a strong height increment at the cost of diameter increment and thus achieve a larger level of slenderness in all diameter classes. This so-called survival strategy (PRETZSCH, 2009) results in shifting height curves to bigger heights. The increase of tree height of specific diameter structures is also based on computation, i.e. it is the consequence of felling shorter trees due to positive selection. This is especially true for thick fir trees on the sample plot 58, with the largest increase in height.

This shift in height curves is not specific for stands with long-term selective manner of management. A long-term consistent application of selective manner of managing stand structures does not change significantly and related to it neither do tree heights of specific diameters. Medium heights of diameter classes in a selective stand tend to achieve a certain state of balance, while achieving possible tree heights for specific stands, which is a suitable measure for stand quality (FLURY, 1929 according MILETIĹ, 1950). In the case of increased target diameter level there can be an 
increase in tree height in higher diameter classes with the decrease or stagnation for tree height of lower diameter classes (FLURY, 1932 according MILETIĹ, 1950).

The changes determined in this paper are changes which occur in the process of creating a selective structure of the stand. In the upcoming period, by creating a selective stand structure and decreasing competition between medium thick and thick trees, height and slenderness level of trees of the same diameter will decrease to a certain extent due to the increase of diameter increment; while the thin tree heights should not experience significant change.

\section{REFERENCES - Literatura}

BONL INA , A. (2011): History, current status and future prospects of uneven-aged forest management in the Dinaric region: an overview. Forestry.

http://forestry.oxfordjournals.org/

BONL INA, A., DEVJAK, T. (2002): Obravnavanje prebiralnih gozdov v gozdnogospodarskem nal rtovanju. Gozdarski vestnik, letnik 60, br. 7-9. S. 317-334. Ljubljana.

DRINIĹ, P. (1974): Dinamika rastenja i priraǵ ivanja bukve, jele i smr!̣ e u najvaǵnijim tipovima bukovo-jelovih ġıma na Igmanu. Radovi Gumarskog fakulteta i Instituta za gimarstvo u Sarajevu, knj. 17, sv. 4-6.

IBRAHIMSPAHIL , A. (2012):-Homogeneity of fir and spruce forest stands in the management unit ñIgmanò. International Scientific Conference ñForests In Future Sustainable Use, Risks And Challengesò. Proceedings. Institute of Forestry. Belgrade.

KLÄDTKE, J. , YUE, CH. (2003): Produktionszielorientierte Entscheidungshilfe für die Bewirtschaftung ungleichaltriger Fichten-Tannen-Wälder und Plenterwälder. Allgemeine Forst und Jagdzeitung. Vol.10-11. S. 196-206.

KOTAR, M. (2003): Ugotavljanje, spremljanje in pomen uravnoteǵenega stanja v prebiralnem gozdu. Gozdarski vestnik, letnik 61, br. 7-8 . S. 283-301. Ljubljana.

KotAR, M. (2005): Zgradba, rast i donos gozda na ekoloġkih in fizioloǵkih osnovah. Zveza gozdarskih druğev Slovenije in Zavod za gozdove Slovenije. Ljubljana.

LUL̦ IĹ, V. (1966): Prilog poznavanju klimatskih odnosa na Igmanu. Radovi Ġumarskog fakulteta i Instituta za ġumarstvo u Sarajevu. Knjiga 10, sv. 2.

MAтḱ, V. (1959): Taksacioni elementi prebornih gima jele, smr!̣ e i bukve na podrul ju Bosne, Radovi Gumarskog fakulteta i Instituta za ġmarstvo i drvnu industriju u Sarajevu, br 4. Sarajevo.

MAтḰ, V. (1980): Prirast i prinos ġuma. Ġmarski fakultet Univerziteta u Sarajevu. Sarajevo. 
Diameter structure and height of trees dynamics of Fir (Abies alba mill.) and Spruce (Picea abies Karst.) stands in management unit ,Igman “(permanent sample plots 43 and 58)

MATḰ, S._et al._(2001): Uzgojni postupci u prebornim ġımama. Obil na jela (Abies alba Mill.) u Hrvatskoj (monografija). S. 40 - 442. Akademija gimarskih znanosti i ĂHrvatske Ġumeñ p-o. Zagreb.

MḳETḰ, G̣. (1950): Osnovi ureLivanja prebirne ġme. Knjiga I. Beograd.

PAVLIL, , J. (1987): Zavrǵni izvjeğaj po istraǵval kom projektu Prirast i prinos mjeg்vitih ġıma bukve, jele i smrl e (u najvaǵnijim tipovima ovih ġıma na podrul ju privredne jedinice ñIgmanò). Gumarski fakultet Univerziteta u Sarajevu.

Pretzsch, H. (2009): Forest Dynamics, Growth and Yeald. Springer-Verlag Berlin Heidelberg, $664 \mathrm{~S}$.

ScHÜTZ, J. P._(1989): Zum Problem der Konkurrenz in Mischbeständen. Schweizerische Zeitschrift für Forstwesen 12, S. 1069-1083.

StefanoviĹ, V. (1984): Vegetacija olimpijskih planina. Biolog̉ki list. Godina XXXI. Broj 9 - 10.

\section{APPENDICES - Prilozi}


Appendix 1. Summary Statistics for $D B H$ of trees

Prilog 1. Deskriptivna statistika prsnih prečnika stabala

\begin{tabular}{|c|c|c|c|c|c|c|c|c|c|c|}
\hline \multirow{4}{*}{$\begin{array}{l}\text { Summary } \\
\text { Statistics }\end{array}$} & \multicolumn{10}{|c|}{ Sample plot } \\
\hline & \multicolumn{5}{|c|}{43} & \multicolumn{5}{|c|}{$\overline{58}$} \\
\hline & \multicolumn{10}{|c|}{ Measurement } \\
\hline & 1 & 2 & 3 & 4 & 5 & 1 & 2 & 3 & 4 & 5 \\
\hline Count & 415 & 419 & 754 & 1228 & 1216 & 856 & 932 & 1216 & 1521 & 1405 \\
\hline Average $(\mathrm{cm})$ & 34,5 & 29,4 & 19,7 & 19,5 & 21,8 & 30,2 & 26,4 & 22,1 & 24,0 & 24,9 \\
\hline Median $(\mathrm{cm})$ & 37,5 & 27,5 & 12,5 & 17,5 & 17,5 & 27,5 & 22,5 & 17,5 & 17,5 & 22,5 \\
\hline Mode $(\mathrm{cm})$ & 37,5 & 12,5 & 12,5 & 12,5 & 12,5 & 12,5 & 12,5 & 12,5 & 12,5 & 12,5 \\
\hline Stnd. dev. $(\mathrm{cm})$ & 12,7 & 16,0 & 11,8 & 11,2 & 11,3 & 15,1 & 16,2 & 12,5 & 13,3 & 12,7 \\
\hline Coeff. of var. (\%) & 36,8 & 54,5 & 60,0 & 57,2 & 51,9 & 50,2 & 61,3 & 56,4 & 55,5 & 50,8 \\
\hline Standard error & 0,6 & 0,8 & 0,4 & 0,3 & 0,3 & 0,5 & 0,5 & 0,4 & 0,3 & 0,3 \\
\hline Minimum $(\mathrm{cm})$ & 12,5 & 12,5 & 12,5 & 12,5 & 12,5 & 12,5 & 12,5 & 12,5 & 12,5 & 12,5 \\
\hline $\operatorname{Maximum}(\mathrm{cm})$ & 62,5 & 67,5 & 62,5 & 72,5 & 82,5 & 82,5 & 92,5 & 72,5 & 82,5 & 77,5 \\
\hline Range $(\mathrm{cm})$ & 50,0 & 55,0 & 50,0 & 60,0 & 70,0 & 70,0 & 80,0 & 60,0 & 70,0 & 65,0 \\
\hline Skewness & $-0,3$ & 0,4 & 1,8 & 2,3 & 1,9 & 0,8 & 1,2 & 1,5 & 1,4 & 1,1 \\
\hline Stnd. skewness & $-2,5$ & 3,3 & 20,6 & 33,5 & 27,3 & 9,6 & 14,4 & 21,4 & 22,3 & 16,1 \\
\hline Kurtosis & $-0,8$ & $-1,2$ & 2,3 & 5,4 & 4,6 & 0,1 & 0,7 & 1,6 & 1,3 & 0,6 \\
\hline Stnd. kurtosis & $-3,3$ & $-5,0$ & 13,0 & 39,0 & 32,8 & 0,5 & 4,2 & 11,7 & 10,7 & 4,6 \\
\hline
\end{tabular}

Appendix 2. Percentage diameter distributions of the number of ingrown (Ni) and felled (Nf) trees

Prilog 2. Procentualna debljinska raspodjela broja uraslih (Ni) $i$

posječenih stabala (Nf)

\begin{tabular}{|c|c|c|c|c|c|c|c|c|c|}
\hline & \multirow{4}{*}{$\begin{array}{l}\text { Diameter } \\
\text { classes }\end{array}$} & \multicolumn{8}{|c|}{ Sample plot } \\
\hline & & \multicolumn{4}{|c|}{43} & \multicolumn{4}{|c|}{58} \\
\hline & & \multicolumn{8}{|c|}{ Between Measurements } \\
\hline & & 1 and 2 & 2 and 3 & 3 and 4 & 4 and 5 & 1 and 2 & 2 and 3 & 3 and 4 & 4 and 5 \\
\hline $\mathrm{Ni}$ & A & 100,0 & 100,0 & 100,0 & 100,0 & 100,0 & 100,0 & 100,0 & 100,0 \\
\hline \multirow{3}{*}{$\mathrm{Nf}$} & $\bar{A}$ & 20,4 & 15,7 & 65,6 & 81,8 & 33,5 & 32,4 & 80,3 & 74,0 \\
\hline & B & 71,0 & 55,1 & 27,1 & 12,2 & 32,1 & 32,5 & 13,1 & 14,8 \\
\hline & $\mathrm{C}$ & 8,6 & 29,2 & 7,3 & 6,0 & 34,4 & 35,1 & 6,6 & 11,2 \\
\hline
\end{tabular}


Diameter structure and height of trees dynamics of Fir (Abies alba mill.) and Spruce (Picea abies Karst.) stands in management unit ,Igman“(permanent sample plots 43 and 58)

Appendix 3. Coefficients of theoretical models of frequency distributions and results KS tests differences empirical and theoretical frequency (DN and p; probability 95\%)

Prilog 3. Koeficijenti teoretskih modela distribucija frekvencija i rezultati KS testa razlika empirijskih i teoretskih frekvencija (DN i p; vjerovatnoća $95 \%)$

\begin{tabular}{|c|c|c|c|c|c|c|c|c|c|c|}
\hline \multirow{3}{*}{$\begin{array}{c}\text { Sample } \\
\text { plot }\end{array}$} & \multirow{3}{*}{\multicolumn{2}{|c|}{ Measurement }} & \multicolumn{8}{|c|}{ Theoretical models } \\
\hline & & & \multicolumn{2}{|c|}{ Normal } & \multicolumn{3}{|c|}{ Gamma (3-parameter) } & \multicolumn{3}{|c|}{ Weibull (3-parameter) } \\
\hline & & & mean & $\begin{array}{l}\text { standard } \\
\text { deviation }\end{array}$ & shape & scale & $\begin{array}{c}\text { lower } \\
\text { threshold } \\
\text { (specified) }\end{array}$ & shape & scale & \begin{tabular}{|c|} 
lower \\
threshold \\
(specified)
\end{tabular} \\
\hline \multirow{15}{*}{43} & \multirow{3}{*}{1} & parameters & 34,464 & 12,672 & 2,068 & 0,085 & 10,000 & 1,853 & 27,183 & 10,000 \\
\hline & & $\mathrm{DN}$ & \multicolumn{2}{|c|}{0,187} & \multicolumn{3}{|c|}{0,216} & \multicolumn{3}{|c|}{0,192} \\
\hline & & $\mathrm{p}$ & \multicolumn{2}{|c|}{$\mathbf{0 , 0 0 0}$} & \multicolumn{3}{|c|}{$\mathbf{0 , 0 0 0}$} & \multicolumn{3}{|c|}{0,000} \\
\hline & \multirow{3}{*}{2} & parameters & 29,362 & 16,011 & 1,051 & 0,054 & 10,000 & 1,057 & 19,770 & 10,000 \\
\hline & & DN & \multicolumn{2}{|c|}{0,210} & \multicolumn{3}{|c|}{0,227} & \multicolumn{3}{|c|}{0,233} \\
\hline & & $\mathrm{p}$ & \multicolumn{2}{|c|}{$\mathbf{0 , 0 0 0}$} & \multicolumn{3}{|c|}{$\mathbf{0 , 0 0 0}$} & \multicolumn{3}{|c|}{$\mathbf{0 , 0 0 0}$} \\
\hline & \multirow{3}{*}{3} & parameters & 19,668 & 11,805 & 1,029 & 0,106 & 10,000 & 0,943 & 9,363 & 10,000 \\
\hline & & DN & \multicolumn{2}{|c|}{0,318} & \multicolumn{3}{|c|}{0,326} & \multicolumn{3}{|c|}{0,298} \\
\hline & & $\mathrm{p}$ & & 000 & & $\mathbf{0 , 0 0}$ & & & 0,000 & \\
\hline & & parameters & 19,516 & 11,153 & 1,183 & 0,124 & 10,000 & 1,017 & 9,595 & 10,000 \\
\hline & 4 & DN & & 291 & & 0,27 & & & $0,24 c$ & \\
\hline & & $\mathrm{p}$ & & 000 & & $\mathbf{0 , 0 0}$ & & & $\mathbf{0 , 0 0 0}$ & \\
\hline & & parameters & 21,801 & 11,310 & 1,326 & 0,112 & 10,000 & 1,131 & 12,392 & 10,000 \\
\hline & 5 & DN & & 214 & & 0,21 & & & 0,19 & \\
\hline & & $\mathrm{p}$ & & 000 & & $\mathbf{0 , 0 0}$ & & & $\mathbf{0 , 0 0 0}$ & \\
\hline & & parameters & 30,175 & 15,140 & 1,445 & 0,072 & 10,000 & 1,289 & 21,777 & 10,000 \\
\hline & 1 & DN & & 137 & & 0,13 & & & 0,13 & \\
\hline & & $\mathrm{p}$ & & 000 & & $\mathbf{0 , 0 0}$ & & & $\mathbf{0 , 0 0 0}$ & \\
\hline & & parameters & 26,411 & 16,183 & 0,997 & 0,061 & 10,000 & 0,980 & 16,262 & 10,000 \\
\hline & 2 & DN & & 205 & & 0,24 & & & 0,236 & \\
\hline & & $\mathrm{p}$ & & 000 & & 0,00 & & & 0,00 & \\
\hline & & parameters & 22,114 & 12,478 & 1,136 & 0,094 & 10,000 & 1,030 & 12,279 & 10,000 \\
\hline 58 & 3 & DN & & 268 & & 0,23 & & & 0,219 & \\
\hline & & $\mathrm{p}$ & & 000 & & $\mathbf{0 , 0 0}$ & & & $\mathbf{0 , 0 0 0}$ & \\
\hline & & parameters & 24,039 & 13,344 & 1,232 & 0,088 & 10,000 & 1,096 & 14,571 & 10,000 \\
\hline & 4 & DN & & 221 & & 0,18 & & & 0,168 & \\
\hline & & $\mathrm{p}$ & & 000 & & $\mathbf{0 , 0 0}$ & & & $\mathbf{0 , 0 0}$ & \\
\hline & & parameters & 24,938 & 12,659 & 1,310 & 0,088 & 10,000 & 1,172 & 15,805 & 10,000 \\
\hline & 5 & DN & & 191 & & 0,18 & & & 0,17 & \\
\hline & & $\mathrm{p}$ & & 000 & & $\mathbf{0 , 0 0}$ & & & $\mathbf{0 , 0 0 0}$ & \\
\hline
\end{tabular}


Appendix 4. The values of coefficients and statistical parameters for the selected regression models of height curves

Prilog 4. Veličine koeficijenata i statističkih pokazatelja odabranih regresionih modela visinskih krivih

\begin{tabular}{|c|c|c|c|c|c|c|c|c|c|}
\hline \multirow{2}{*}{$\begin{array}{c}\text { Sample } \\
\text { plot }\end{array}$} & \multirow{2}{*}{ Spesiec } & \multirow{2}{*}{$\begin{array}{c}\text { Measure } \\
\text { ment }\end{array}$} & \multicolumn{3}{|c|}{ Coefficients of functions } & \multirow{2}{*}{$\mathrm{R}$} & \multirow{2}{*}{$\mathrm{R}^{2}$} & \multirow{2}{*}{$\mathrm{S}_{\mathrm{ey}}{ }^{2}$} & \multirow{2}{*}{$\mathrm{N}$} \\
\hline & & & $\mathrm{a}$ & b & $\mathrm{c}$ & & & & \\
\hline \multirow{4}{*}{43} & \multirow{2}{*}{$\mathrm{JL}$} & 2 & 0,033 & $-0,112$ & 22,525 & 0,998 & 0,996 & 0,255 & 612 \\
\hline & & 5 & 0,027 & 0,514 & 4,239 & 0,942 & 0,887 & 3,844 & 141 \\
\hline & \multirow{2}{*}{ SM } & 2 & 0,026 & 0,300 & 16,410 & 0,995 & 0,989 & 0,440 & 147 \\
\hline & & 5 & 0,024 & 0,467 & 5,733 & 0,970 & 0,940 & 3,860 & 70 \\
\hline \multirow{4}{*}{58} & \multirow{2}{*}{$\mathrm{JL}$} & 2 & 0,033 & 0,097 & 18,239 & 0,998 & 0,997 & 1,311 & 555 \\
\hline & & 5 & 0,028 & 0,361 & 10,517 & 0,976 & 0,953 & 3,813 & 114 \\
\hline & \multirow{2}{*}{ SM } & 2 & 0,031 & 0,097 & 18,595 & 0,998 & 0,996 & 0,879 & 344 \\
\hline & & 5 & 0,031 & 0,051 & 14,250 & 0,960 & 0,922 & 8,439 & 131 \\
\hline
\end{tabular}

\section{SAŽETAK}

U radu je analizirana dinamika debljinskih struktura i visinskih krivih, kao osnovnih pokazatelja jednostavne strukture sastojina, raznodobnih viǵespratnih sastojina jele $\mathrm{i}$ smrl e u GJ Âgmanñu kojim se provode preborne sjel e bazirane na principu pozitivne selekcije. Pri tome su koriġeni podaci koji su prikupljeni periodil nim premjerima tokom 50 godina na dvije stalne ogledne plohe u ğmskim odjeljenjima 43 i 58.

UtvrL'eno je da debljinske strukture prvog premjera, zbog znal ajnog udjela srednje debelih stabala, odstupaju od oblika koji je karakteristil an za preborne sastojine i podsjel aju na debljinsku strukturu jednodobnih sastojina. Ove debljinske strukture su vremenom uz sjeḷe debelih i srednje debelih stabala, razvoj novog i postojel eg podmlatka, te prirast stabala i prelazak u naredni viğ ili viğe debljinske stepene postepeno prevedene u debljinske strukture oblika karakteristi!lnog za preborne sastojine. Uz to je, zbog poveĺanja konkurencije izmeĹu stabala niğih debljinskih klasa i sjel e niğih i nekvalitenijih stabala viğh debljinskih klasa, doğlo do povel anja visina stabala u cijelom intervalu empirijskih podataka, odnosno pomjeranja visinskih krivih prema vel im visinama stabala.

Zakljul eno je da se primjenom prebornih sjel a na principu pozitivne selekcije vremenom postepeno formira debljinska struktura uz koju je obezbijeĹeno funkcionisanje sastojine kao preborne, a visine stabala se mijenjaju prema visinama koje su realno mogul e na datom staniğu i tek tada se mogu koristiti kao pogodan indikator proizvodnog potencijala staniğa. 